\title{
Intraoperative body temperature control: esophageal thermometer versus infrared tympanic thermometer
}

\author{
Controle da temperatura corporal no intraoperatório: \\ termômetro esofágico versus termômetro timpânico \\ Control de la temperatura corporal en el intraoperatorio: \\ termómetro esofágico versus termómetro timpánico
}

\author{
Vanessa de Brito Poveda ${ }^{1}$, Ariane de Souza Nascimento ${ }^{2}$
}

How to cite this article:

Poveda VB, Nascimento AS. Intraoperative body temperature control: esophageal thermometer versus infrared tympanic thermometer. Rev Esc Enferm USP. 2016;50(6):945-950. DOI: http://dx.doi.org/10.1590/S0080-623420160000700010

${ }^{1}$ Universidade de São Paulo, Escola de Enfermagem, Departamento de Enfermagem Médico-Cirúrgica, São Paulo, SP, Brazil.

${ }^{2}$ Universidade de São Paulo, Escola de Enfermagem, São Paulo, SP, Brazil.

\begin{abstract}
Objective: To verify the correlation between temperature measurements performed using an infrared tympanic thermometer and an esophageal thermometer during the intraoperative period. Method: A longitudinal study of repeated measures was performed including subjects aged 18 years or older undergoing elective oncologic surgery of the digestive system, with anesthesia duration of at least 1 hour. Temperature measurements were performed simultaneously by a calibrated esophageal thermometer and by a calibrated infrared tympanic thermometer, with laboratory reading precision of $\pm 0.2^{\circ} \mathrm{C}$. The operating room temperature remained between 19 and $21^{\circ} \mathrm{C}$. Results: The study included 51 patients, mostly men (51\%), white (80.4\%). All patients were kept warm by a forced-air heating system, for an average of 264.14 minutes $(\mathrm{SD}=87.7)$. The two temperature measurements showed no different behavior over time $(p=0.2205)$, however, tympanic measurements were consistently $1.24^{\circ} \mathrm{C}$ lower $(p<0.0001)$. Conclusion: The tympanic thermometer presented reliable results but reflected lower temperatures than the esophageal thermometer.
\end{abstract}

\section{DESCRIPTORS}

Hypothermia; Body Temperature; Thermometers; Perioperative Nursing. 


\section{INTRODUCTION}

Intraoperative hypothermia, defined as body temperature lower than $36^{\circ} \mathrm{C}$ during an anesthetic-surgical procedure, should be a constant concern of the multiprofessional team due to its high frequency and association with several complications that affect patient recovery, among them being: alteration of drug metabolism; increase in the metabolic demand promoted by the occurrence of postoperative chills; and predisposition to changes in the coagulation cascade and platelet function ${ }^{(1-3)}$.

In order to prevent the occurrences mentioned above, scientific literature has explored the need for continuous and systematic use of warming measures during the perioperative period ${ }^{(4-6)}$; however, in order to ensure patient safety regarding the adopted measures, a precise body temperature measurement is needed.

Currently, different forms of temperature measurement are available which can indicate core or peripheral temperature, as well as instruments that provide core temperature measurements, meaning those that indicate the temperature of the carotid artery blood supply, being responsible for the blood supply to the organism's thermoregulatory center (the hypothalamus) $)^{(4,7)}$.

In general, methods that indicate core body temperature are invasive, and for this reason they are associated with a greater number of complications and/or infectious problems ${ }^{(7)}$. Thus, non-invasive measures are expected to be able to provide reliable and safe measurements of the patient's body temperature.

Body temperature can be obtained in several places of the body, such as the axilla, nasopharynx, esophagus, rectum, tympanic membrane, temporal artery, pulmonary artery and bladder; however, only the measurements performed on the tympanum, esophagus, nasopharynx and pulmonary artery can more accurately portray the temperature referred to as core temperature ${ }^{(1,4)}$.

It should be noted that some of these forms of measurement are not indicated for intraoperative surgical patients due to the specific needs of subjects subjected to anestheticsurgical procedures who are often exposed to intubation, manipulation of organs and spaces or to specific positions to ensure the success of the surgery ${ }^{(8-9)}$.

Thus, the most frequently used intraoperative temperature measurements are through the pulmonary artery, nasopharynx and esophagus. The ideal choice is based on the type of specialty or surgical procedure to be performed. It is emphasized that in Brazil, the placement of these devices for measuring core temperature is often performed by the anesthesiologist or by the surgeon.

Among the core temperature measurements, esophageal temperature is the best combination of performance, cost-effectiveness and safety. It is an invasive procedure that should not be recommended for patients only subjected to regional anesthesia, who may feel discomfort during its placement and maintenance; furthermore, if the tip of the sensor is positioned in the distal third of the esophagus, the temperature of inhaled gases may interfere with the patient's body temperature measurement ${ }^{(1,10)}$.
Tympanic temperature measurement would be a less invasive method of measuring core temperature, and it would reflect the temperature of the external carotid artery by using a device located near the tympanic membrane ${ }^{(8)}$.

An integrative review of the literature compared 23 studies in which invasive methods such as temperature measurement in the pulmonary artery and esophagus, and non-invasive methods such as tympanic, temporal artery and oral temperature were used in severely ill adult patients. The results showed strong evidence related to the accuracy of tympanic temperature measurements, thus being the preferred method for non-invasive measurement of core temperature in many critical care units ${ }^{(11)}$.

Therefore, the American Society of PeriAnesthesia Nurses (ASPAN) recommends the measurement of tympanic temperature as the non-invasive method of perioperative temperature control ${ }^{(12)}$.

This method of measuring temperatures has obvious advantages to the perioperative nursing practice, since it allows the body's body temperature to be measured using a non-invasive method that can reflect a temperature close to core temperatures, with little or no inconvenience regarding the positioning or choice of anesthetic technique, depending on the medical specialization.

Infrared tympanic thermometers are currently available on the market ${ }^{(8)}$. Problems related to the reliability of their results, in the sense of actually reflecting the tympanic temperature and not the temperature of the auditory canal or the environment have been corrected ${ }^{(13-14)}$.

As the reading of vital signs (with temperature among them) are frequently performed by the nursing team ${ }^{(7)}$, it is interesting to know and understand the practical application of the tympanic thermometer in intraoperative temperature measurement, thus guaranteeing an independent performance of perioperative nursing in relation to patients' body temperature control throughout the perioperative period, as well as a more adequate control of body temperature maintenance devices.

Accordingly, we propose the present investigation with the intention of understanding how this reality would happen in daily practice with instruments that are available in hospital institutions, seeking to estimate the confidence in a non-invasive method of intraoperative body temperature measurement via the tympanic membrane, and comparing it to an invasive method of the esophageal temperature measurement, as practiced in the hospital institution selected for conducting the present study.

Therefore, the present study aimed to compare the temperature measurements of infrared thermometer and esophageal thermometer during the intraoperative period and to verify the correlation between the measurements of tympanic and esophageal temperatures.

\section{METHOD}

The proposed study was developed using the quantitative methodological approach, with a quasi-experimental, longitudinal research design of repeated measures. 
The selected site for the development of the study was a hospital located in the state of São Paulo, specialized in oncology research and care.

The research project was submitted and approved by the Research Ethics Committee of the School of Nursing under the number 599.703-0, after authorization from the hospital according to Resolution 466/12 of the National Health Council, which regulates research on human beings ${ }^{(15)}$.

The study included patients aged 18 years or over at the time of data collection, submitted to elective oncologic surgery of the digestive system with anesthesia duration of at least 1 hour. Exclusion criteria were body temperature equal to or greater than $38^{\circ} \mathrm{C}$ at the time of admission to the surgical procedure or the presence of any kind of endocrine problem.

The instrument used for data collection contained data referring to the sociodemographic characterization of individuals, specific situations of the anesthetic-surgical procedure and information regarding patient's body temperature measurement during reception at the surgical center, anesthetic induction and the intraoperative period.

Thus, on the day of surgery, the researcher at the reception of the surgical center informed the subject of the objectives of the study and if the patient agreed to participate they were asked to sign the Informed Consent Form.

The patient was then admitted to the operating room, underwent anesthesia and installation of a calibrated esophageal thermometer (Dixtal Biomédica Ind. Com. Ltda. ${ }^{\circledR}$ ) by the anesthesiologist responsible in the operating room. The disposable thermometer consists of a thin plastic tube, inserted through the nostril or oral cavity into the esophagus to approximately $45 \mathrm{~cm}$, ideally positioned between the left ventricle and the aorta, between the eighth and ninth thoracic vertebrae ${ }^{(16)}$.

Measurement of the patient's tympanic temperature was performed with a calibrated infrared tympanic thermometer (ProCheck ${ }^{\circledR}$ ) with a laboratory reading accuracy of $\pm 0.2^{\circ} \mathrm{C}$. All measurements were taken from the same ear in order to avoid inducing systematic errors in measuring the variable.

Esophageal and tympanic temperature monitoring was then performed upon the patient's arrival into the operating room (before commencing the warming systems), at the beginning of induced anesthesia, at the beginning of surgery, and thereafter at every 20 minutes until the end of the anesthetic-surgical procedure. Room temperature was maintained by central air conditioning, between 19 and $21^{\circ} \mathrm{C}$.

Through intraclass correlation coefficient (ICC) it was estimated that approximately 38 patients could be included in the present investigation in order to detect coefficients higher than $0.5^{\circ} \mathrm{C}$, with confidence and power of $95 \%$, considering the two measurements (esophageal and tympanic temperature measurements).

The results were presented according to statistical descriptive measures such as arithmetic average, standard deviation, and median, as well as minimum and maximum values for continuous variables. The evolution of average temperatures in the two instruments was evaluated by a mixed effects model (and first-order autoregressive covariance structure). Double data entry technique was used and the collected data was analyzed using the software Statistical Package for the Social Sciences (SPSS 10.0). The significance level used was $\alpha=0.05$.

\section{RESULTS}

Fifty-one (51) patients were included, where tympanic and esophageal temperatures were simultaneously measured for each.

Most of the sample consisted of white $(80.4 \%)$ men (51\%) who had undergone prior chemotherapy (56.9\%), and only $23.5 \%$ had undergone radiotherapy. The average body mass index $(\mathrm{BMI})$ was $24.91 \mathrm{~kg} / \mathrm{m}^{2}(\mathrm{SD}=4.41)$, minimum value of 16.22 and maximum of $34.48 \mathrm{~kg} / \mathrm{m}^{2}$.

All patients were warmed using the forced-air heating system for an average of 264.14 minutes $(\mathrm{SD}=87.7)$, with a minimum of 65 and a maximum of 427 minutes.

The majority of the patients underwent balanced general anesthesia combined with epidural anesthesia (78.4\%), and mainly underwent stomach (35.3\%) and rectal (21.5\%) surgeries. Anesthetic and surgical procedures had an average duration of 360.1 and 250.4 minutes, respectively (Table 1 ).

Table 1 - Variables related to the anesthetic-surgical procedure - São Paulo, SP, Brazil, 2014.

\begin{tabular}{|c|c|c|c|c|}
\hline Variables & $N(\%)$ & Average (standard deviation) & Median & Minimum-Maximum \\
\hline \multicolumn{5}{|l|}{ Type of anesthesia } \\
\hline General balanced + epidural & $40(78.4)$ & & & \\
\hline $\begin{array}{l}\text { General } \\
\text { balanced + spinal anesthesia }\end{array}$ & $7(13.7)$ & & & \\
\hline General & $4(7.8)$ & & & \\
\hline \multicolumn{5}{|l|}{ ASA Classification* } \\
\hline $\begin{array}{l}\text { ASA1 } \\
\text { ASA2 } \\
\text { ASA3 }\end{array}$ & $\begin{array}{c}3(5.9) \\
35(68.6) \\
13(25.5)\end{array}$ & & & \\
\hline \multicolumn{5}{|l|}{ Type of surgery } \\
\hline Total and partial gastrectomy & $18(35.3)$ & & & \\
\hline Abdominal rectosigmoidectomy & $11(21.5)$ & & & \\
\hline
\end{tabular}


...continuation

\begin{tabular}{lcccc}
\hline \multicolumn{1}{c}{ Variables } & N (\%) & Average (standard deviation) & Median & Minimum-Maximum \\
\hline Pancreaticoduodenectomy & $10(19.6)$ & & & \\
Hepatectomy & $5(9.8)$ & & & \\
Others & $7(13.7)$ & & 365 & $150-555$ \\
Duration of anesthesia & & $360.1(93.4)$ & 245 & $60-420$ \\
Duration of surgery & & $250.4(85.9)$ & 6.000 & $2.500-11.500$ \\
Infused Volume & & $6.019 .6(1.788 .7)$ & &
\end{tabular}

*ASA: American Society of Anesthesiologists.

Regarding temperature analysis, it was noticed that despite being constant, tympanic temperatures were lower for all measurements; approximately one degree lower than esophageal temperatures (Figure 1).
Both temperature measurements showed no difference in behavior over time $(\mathrm{p}=0.2205)$, however tympanic measurements were consistently lower at $1.24^{\circ} \mathrm{C}$ $(\mathrm{p}<0.0001)$.

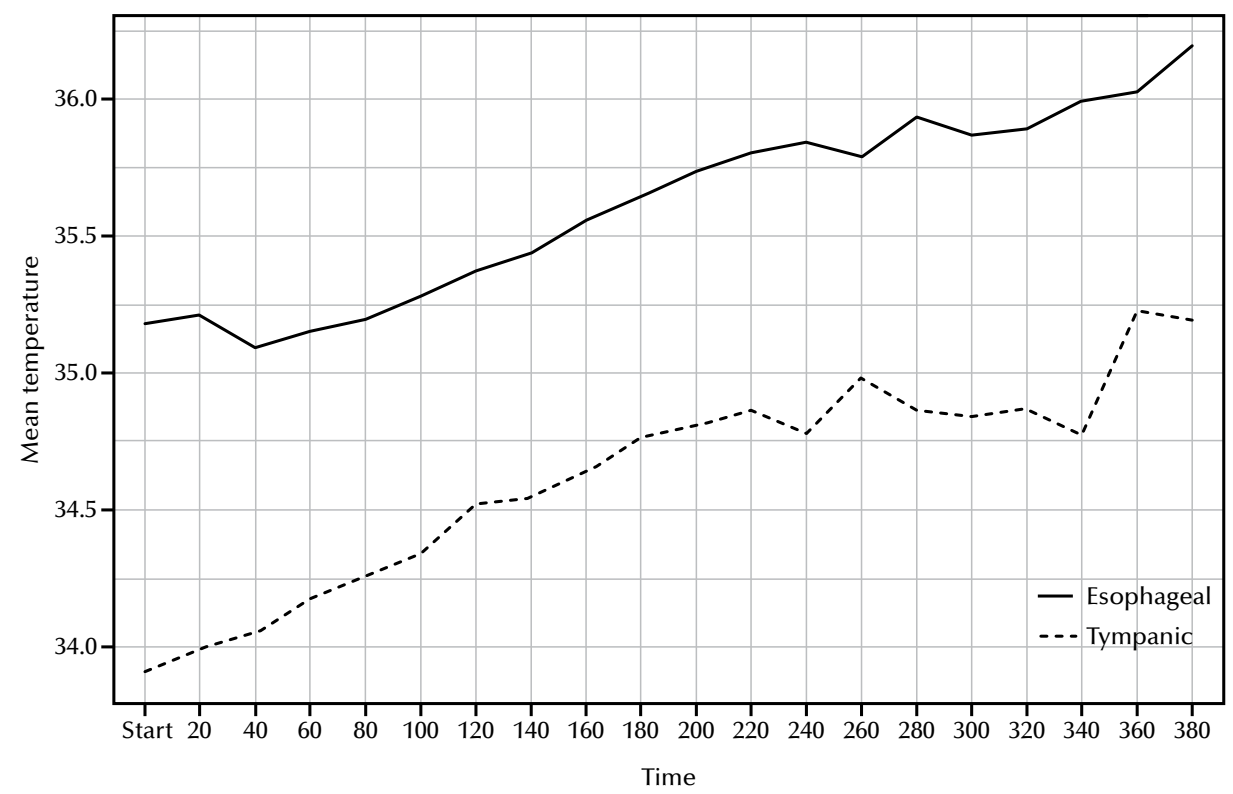

Figure 1 - Difference between esophageal and tympanic temperature measurements - São Paulo, SP, Brazil, 2014.

\section{DISCUSSION}

The tympanic method of measuring temperatures showed a lower performance than the core temperature obtained by the esophageal thermometer, evidencing temperatures approximately one degree lower, however both measurement forms maintained similar behavior over time. It should be noted that both forms of measurement were performed in the same patient and repeated on all subjects of the sample.

Among the core temperature measures, pulmonary artery readings are the most accurate form of measurement; nevertheless, it is an invasive procedure that brings risks to the patient, such as dysrhythmias, infection and damage to the heart valves caused by the need of introducing the Swan Ganz catheter. Thus, this measuring instrument should only be used when considered essential for patient treatment, considering other functionalities of the catheter and not just body temperature measurement ${ }^{(4,8,17-19)}$.

Thus, esophageal temperature measurement is often used in the intraoperative period due to the perfusion proximity to great vessels to the heart, and providing values that are close to those obtained in the pulmonary artery ${ }^{(1,20)}$.

Previous investigations have also observed that temperature measurements of infrared tympanic thermometers obtain lower temperature measurements when compared with estimates of core temperature, such as rectal measurement, for example ${ }^{(14,21)}$. However, it is worth noting that even when comparing core temperature measures such as esophageal and nasopharyngeal in the same patient, a statistically significant difference of approximately $0.2^{\circ} \mathrm{C}$ was found between both measurements ${ }^{(22)}$.

Also regarding the performance of different types of thermometers and their ability to estimate body temperature, a recent study comparing invasive (rectal) and non-invasive temperature measurements (tympanic, infrared skin, temporal artery) between a heterogeneous group of children observed the following temperature variations as measured between the group undergoing rectal temperature measurement and those measured by infrared tympanic thermometer $\left(0.49^{\circ} \mathrm{C}\right)$; of the skin by infrared $\left(0.34^{\circ} \mathrm{C}\right)$, and; finally, by the temporal artery $\left(0^{\circ} \mathrm{C}\right)$, respectively ${ }^{(21)}$. 
Another investigation comparing the reliability and validity of infrared tympanic thermometers also observed statistically significant differences between the values obtained in comparing different brands of infrared tympanic thermometers and rectal temperature measurement which varied between 0.36 and 0.85 . It is noteworthy that in patients admitted to Intensive Care Units (ICU), where the temperature measurement was performed through the pulmonary artery, the rectal temperature exceeded this measurement, and the temperature obtained by the tympanic thermometer was closer to the pulmonary artery temperature (considered the standard) ${ }^{(14)}$.

Therefore, the differences between measurements exist, both in the comparison between central thermometers as well as in the comparison between central and peripheral thermometers; however, in the latter case the differences appear to be greater ${ }^{(14)}$. This fact could possibly be due to the influence of the operating room temperature on the measurement obtained by the tympanic thermometer ${ }^{(13)}$.

Another aspect to be discussed is even though the measurement of the tympanic temperature has good correlation in relation to core temperature, variations can occur between measurements performed by different professionals, thus requiring adequate technical training to obtain reliable results ${ }^{(14)}$.

Some advantages of the tympanic thermometer in addition to its ability to measure exact and safe temperatures should be highlighted; among them, the speed and practicality of its use, as well as its non-invasive character ${ }^{(23)}$.

Given the diversity of options for temperature gauging, the choice of the ideal thermometer for each clinical situation pervades not only its ability to adequately measure body temperature at any age, but it should also be: safe, cost-effective, quick to measure, convenient, simple and comfortable for patient and the health team, it should not have its measurements affected by ambient temperature, there should be no possibility of cross-infection, and it should be easy to calibrate ${ }^{(24)}$.
Therefore, it is expected that clinical nurses are equipped with up-to-date technical and scientific knowledge to consciously choose the best strategy for controlling their patients' body temperature, especially taking into consideration the best method depending on the clinical condition and situation experienced.

The results of the present study have immediate application in clinical practice, equipping nurses with a fundamental choice of more reliable temperature measurement methods. However, a limitation of this investigation should be noted that due to the proposed research design, only one brand/ model of tympanic thermometer was used in a homogeneous group of patients submitted to elective oncological surgical procedures of the digestive system.

Thus, we recommend that nurses take ownership of this knowledge and conduct new investigations, reporting their experiences with this tool in different clinical settings and compare them to the usual employed practices, gradually incorporating new technologies that optimize their work and guarantee greater comfort, quality and security to patient care into their activities.

\section{CONCLUSION}

The temperatures measured by the tympanic thermometer were on average $1.24^{\circ} \mathrm{C}$ lower than those measured by the esophageal thermometer, however, the two forms of temperature gauging showed similar behaviors.

Nurses must be aware that the infrared tympanic thermometer, despite being a reliable tool records lower temperatures than those obtained by central thermometers.

We suggest further studies in clinical practice that verify the influence of the ambient temperature on the measurement of tympanic temperature by infrared thermometer and possible differences between measurements obtained by different brands/models.

\section{RESUMO}

Objetivo: Verificar a correlação entre as medidas de temperatura realizadas por meio de um termômetro timpânico por infravermelho e por um termômetro esofágico, durante o período intraoperatório. Método: Realizou-se um estudo longitudinal, de medidas repetidas, incluindo sujeitos com idade igual ou superior a 18 anos, submetidos à cirurgia oncológica eletiva do sistema digestório, com duração da anestesia de, no mínimo, 1 hora. As medidas de temperatura eram realizadas, ao mesmo tempo, por meio de um termômetro esofágico calibrado e por termômetro timpânico por infravermelho calibrado, com precisão de leitura em laboratório de $\pm 0,2^{\circ} \mathrm{C}$. A temperatura da sala operatória permaneceu entre 19 e $21^{\circ} \mathrm{C}$. Resultados: Foram incluídos 51 pacientes, em sua maioria homens (51\%), brancos (80,4\%). Todos os pacientes foram aquecidos com o sistema de ar forçado aquecido, em média por 264,14 minutos $(\mathrm{DP}=87,7)$. As duas medidas de temperatura não tiveram comportamento diferente ao longo do tempo $(p=0,2205)$, mas a medida timpânica foi consistentemente menor em $1,24^{\circ} \mathrm{C}(p<0,0001)$. Conclusão: $\mathrm{O}$ termômetro timpânico apresentou resultados confiáveis, mas refletiu temperaturas mais baixas do que o termômetro esofágico.

DESCRITORES

Hipotermia; Temperatura Corporal; Termômetros; Enfermagem Perioperatória.

\section{RESUMEN}

Objetivo: Verificar la correlación entre las medidas de temperatura realizadas por medio de un termómetro timpánico por infrarrojo y por un termómetro esofágico, durante el período intraoperatorio. Método: Se llevó a cabo un estudio longitudinal, de medidas repetidas, incluyendo a sujetos con edad igual o superior a 18 años, sometidos a la cirugía oncológica electiva del sistema digestivo, con duración de la anestesia de, como mínimo, una hora. Las mediciones de temperatura eran realizadas a la vez por medio de un termómetro esofágico calibrado y un termómetro timpánico por infrarrojo calibrado, con precisión de lectura en laboratorio de $\pm 0,2^{\circ} \mathrm{C}$. La temperatura del quirófano permaneció entre 19 y $21^{\circ} \mathrm{C}$. Resultados: Fueron incluidos 51 pacientes, en su mayoría hombres (51\%), blancos (80,4\%). Todos los pacientes se calentaron con el sistema de aire forzado de calefacción, en promedio por 264,14 minutos $(\mathrm{DP}=87,7)$. Ambas 
mediciones de temperatura no tuvieron comportamiento distinto a lo largo del tiempo $(p=0,2205)$, pero la medida timpánica fue consistentemente menor en $1,24^{\circ} \mathrm{C}(p<; 0,0001)$. Conclusión: El termómetro timpánico presentó resultados confiables, pero reflejó temperaturas más bajas que el termómetro esofágico.

\section{DESCRIPTORES}

Hipotermia; Temperatura Corporal; Termómetros; Enfermería Perioperatoria.

\section{REFERENCES}

1. Weirich TL. Hypothermia/warming protocols: why are they not widely used in the OR? AORN J. 2008;87(2):333-44.

2. Nieh HC, Su SF. Meta-analysis: effectiveness of forced-air warming for prevention of perioperative hypothermia in surgical patients. J Adv Nurs. 2016;72(10):2294-314.

3. Rowley B, Kerr M, Van Poperin J, Everett C, Stommel M, Lehto RH. Perioperative warming in surgical patients: a comparison of interventions. Clin Nurs Res. 2015;24(4):432-41.

4. Association of PeriOperative Registered Nurses (AORN). Guideline for perioperative practice. Denver: AORN; 2016. Guideline for prevention of unplanned patient hypothermia; p. 531-54.

5. Madrid E, Urrútia G, Roqué i Figuls M, Pardo-Hernandez H, Campos JM, Paniagua P, et al. Active body surface warming systems for preventing complications caused by inadvertent perioperative hypothermia in adults. Cochrane Database Syst Rev. 2016;(4):CD009016.

6. Fettes S, Mulvaine M, Van Doren E. Effect of preoperative forced-air warming on postoperative temperature and postanesthesia care unit length of stay. AORN J. 2013; 97(3):323-8.

7. Basak T, Aciksoz S, Tosun B, Akyuz A, Acikel C. Comparison of three different thermometers in evaluating the body temperature of healthy young adult individuals. Int J Nurs Pract. 2013;19(5):471-8.

8. Torossian A. Thermal management during anaesthesia and thermoregulation standards for the prevention of inadvertent perioperative hypothermia. Best Pract Res Clin Anaesthesiol. 2008;22(4):659-68.

9. Wang M, Singh A, Qureshi H, Leone A, Mascha EJ, Sessler DI. Optimal depth for nasopharyngeal temperature probe positioning. Anesth Analg. 2016;122(5):1434-8.

10. Snoek AP, Saffer E. Agreement between lower esophageal and nasopharyngeal temperatures in children ventilated with an endotracheal tube with leak. Paediatr Anaesth. 2016;26(2):213-20.

11. Hooper VD, Andrews JO. Accuracy of noninvasive core temperature measurement in acutely ill adults: the state of the science. Biol Res Nurs. 2006;8(1):24-34

12. Hooper VD, Chard R, Clifford T, Fetzer S, Fossum S, Godden B, et al. ASPAN's evidence-based clinical practice guideline for the promotion of perioperative normothermia: second edition. J Perianesth Nurs. 2010;25(6):346-65.

13. Salota V, Slovakova Z, Panes C, Nundlall A, Goonasekera C. Is postoperative tympanic membrane temperature measurement effective? Br J Nurs. 2016;25(9):490-3

14. Haugan B Langerud AK, Kalvoy H, Froslie KF, Riise E, Kapstad H. Can we trust the new generation of infrared tympanic thermometers in clinical practice? J Clin Nurs. 2013;22(5-6):698-709.

15. Brasil. Ministério da Saúde; Conselho Nacional de Saúde. Resolução n. 466, de 12 de dezembro de 2012. Dispõe sobre diretrizes e normas regulamentadoras de pesquisas envolvendo seres humanos [Internet]. Brasília; 2012 [citado 2016 mar. 21]. Disponível em: http:// conselho.saude.gov.br/ultimas_noticias/2013/06_jun_14_publicada_resolucao.html

16. Basset FA, Cahill F, Handrigan G, Ducharme MB, Cheung SS. The effect of lower body cooling on the changes in three core temperature indices. Physiol Meas. 2011;32(4):385-94.

17. Hakata S, Ota C, Kato Y, Fujino Y, Kamibayashi T, Hayashi Y. An analysis of the factors influencing pulmonary artery catheter placement in anesthetized patients. Ann Card Anaesth. 2015;18(4):474-8.

18. Guschlbauer M, Maul AC, Yan X, Herff H, Annecke T, Sterner-Kock A, et al. Zero-heat-flux thermometry for non-invasive measurement of core body temperature in pigs. PLoS One. 2016;11(3):e0150759.

19. Shin J, Kim J, Song K, Kwak Y. Core temperature measurement in therapeutic hypothermia according to different phases: Comparison of bladder, rectal, and tympanic versus pulmonary artery methods. Resuscitation. 2013;84(6):810-7.

20. Sarkar S, Donn SM, Bhagat I, Dechert RE, Barks JD. Esophageal and rectal temperatures as estimates of core temperature during therapeutic whole-body hypothermia. J Pediatr. 2013;162(1):208-10.

21. Allegaert K, Casteels K, van Gorp I, Bogaert G. Tympanic, infrared skin, and temporal artery scan thermometers compared with rectal measurement in children: a real-life assessment. Curr Ther Res Clin Exp. 2014;76:34-8.

22. Erdling A, Johansson A. Core temperature: the intraoperative difference between esophageal versus nasopharyngeal temperatures and the impact of prewarming, age, and weight: a randomized clinical trial. AANA J. 2015;83(2):99-105.

23. Gasim GI, Musa IR, Abdien MT, Adam I. Accuracy of tympanic temperature measurement using an infrared tympanic membrane thermometer. BMC Res Notes. 2013;6:194.

24. El-Radhi AS. Temperature measurement: the right thermometer and site. Br J Nurs. 2013;22(4):208, 210-1.

Financial support: Fundação de Amparo à Pesquisa do Estado de São Paulo (FAPESP). Project FAPESP 2013/15536-3. 